Journal of Mathematics and Informatics

Vol. 18, 2020, 15-31

ISSN: 2349-0632 (P), 2349-0640 (online)

Published 1 January 2020

www.researchmathsci.org

DOI: http://dx.doi.org/10.22457/jmi.v18a2159

Journal of

Mathematics and

Informatics

\title{
The Impacts of Tour Guide Performance on Word of Mouth Recommendation of Chinese Tourists in Vietnam
}

\author{
Pham Van Sang \\ School of Economics and Management \\ Chongqing University of Posts and Telecommunications, China-400060 \\ Email: sangvpham95@gmail.com
}

Received 1 December 2019; accepted 24 December 2019

\begin{abstract}
This paper aimed to identify the impacts of tour guide performanceaffecting the Word-of-Mouth (WOM) recommendation of Chinese tourists in Vietnam. The sample in this research comprised 449 tourists in Danang city who were currently on or had previously been on a group package tour within the past few months. The results showed that the performance of tour guide plays an important role in the satisfaction and WOM of Chinese tourists. The study determined factors of tour guide performance such as appearance, empathy, work attitude, communication skill, organizational skill, problemsolving skill, professional competence. Moreover, this study also provides many suggestions for local tour guides and tour managers.
\end{abstract}

Keywords: tour guide performance; Chinese tourists; tourist satisfaction; WOM recommendation; Danang city

\section{AMS Mathematics Subject Classification (2010): 97K 80}

\section{Introduction}

Asia has recently become one of the fastest developing destinations in the world. The middle class in Asia is expanding rapidly and traveling more widely. Vietnam has a considerable attraction in this market and further development potential.Consumers from large markets which have a huge number of travelers every yearsuch as China are looking for relaxation, but sometimes they cannot afford to have long haul travel. Therefore, they prefer neighboring countries when choosing the destination for their travel. Besides, Vietnam enjoys a firm relationship with Chinese tourists, who make up a significant proportion of its international arrivals - in 2017, 4 million of the 12.9 million visitors hailed from its northern neighbor. As we can see that Chinese tourists are anenormous source of Vietnam's tourism, so the researches on Chinese tourists are more and more becoming an interesting topic. Previous international studies which have investigated in the field of Chinese tourists are the behavior of Chinese outbound tourists [1], the characteristics and satisfaction of Chinese tourists to Hong Kong [2]. In terms of the relationship between Chinese tourist and local tour guide, although some researches on the tour guide performance and its impact on tourist satisfaction and the WOM intention have been conducted in countries like Hong Kong, Macau, and China [3][4], there is lack of academic researches on this in Vietnam. The coverage of this research will determine 
The Impacts of Tour Guide Performance on Word of Mouth Recommendation of Chinese Tourists in Vietnam

the factors associated with the tourist satisfaction and WOM of Chinese travelers as an example of Danang city. Finally, from the empirical evidence and the relationships between factors, the study can help tourism managers and stakeholders to better understand the experience of tourists and formulate the best strategies to attract more tourists.

\section{Literature review}

\subsection{Tour guide background}

Tour guides are frontline employees in the tourism industry who play a significant role in drawing tourists to a destination. Tour guiding service is the principal component of tour services offered by tourism companies. Whether tour guides can deliver quality service to tourists is not only necessary to the business success but also critical to the image of the destination [4]. The content of the works that the tour guide must do such as organizing tours, explaining and guiding the organization of activities; tour guide must have general and in-depth knowledge of destinations in the tour program; they must have information transfer skill to create excitement and trust for tourists; last but not least, they must have virtuous character[6]. [7] showed the role of tour guides based on conditions and environment in many studies since 1981 and concluded that the tour guide role depends on the objectives of the tour group. Tour guides can be, for instance, an actor, ambassador, translator, organizer, entertainer, team leader, teacher, host/hostess, caregiver, company representative, motivator, environmentalist, linguist, cultural operator, geographer, cultural mediator, public relations personnel and travel protector.

Service quality of tour guide plays a huge role for travel companies. The service quality of a tour guide can be evaluated through three main constructs:

- $\quad$ The core service delivery: the essence of a tour guide's service which the guide must deliver with consistency.

- $\quad$ The customer orientation: the extent the guide puts the tourists' needs and interests ahead of his own in providing superior value to tourists.

The communication effectiveness: the exchange of information [8].

Good service quality of tour guides will bring a lot of benefits for tourists, travel companies, for the country. For example, if a tour guide enthusiastically guides and cares about visitors, it will definitely make visitors happy with the trip. Professional qualifications and skills, as well as an easy-going attitude of the tour guide, will make visitors trust in ensuring the service quality in each trip. Improving the quality of tour guides is to bring service quality to a higher level in order to satisfy the expectations of tourists and society and bring efficiency to businesses. Tourists are likely to give their friends, relatives recommendations if they were satisfied with the overall package[9].

In Vietnam, few researchers have paid attention to tourist satisfaction and WOM recommendation [10][11]. Using the Holiday Satisfaction (HOLSAT) model, [10] measured Australian tourists' satisfaction with the holiday experience in Vietnam, but not with specific service providers (such as tour guides). Another study by [11] also aimed to assess the satisfaction levels of Chinese tourists in Vietnam with tourism products in general. Because of this reason, it can be said that there is a very little research focusing on tourist satisfaction and WOM on a specific service in Vietnam or a specific group of tourists, which leads the difficulty and debate for researchers when choosing the 
Pham Van Sang

appropriate methods and models to assess the tourist satisfaction on tour guide performance. It would, therefore, be useful to conduct empirical research on different destinations to make further improvements and refinements on the model of the relationship between tour guide performance and tourist satisfaction. In order to fill this gap, this research aimed partly to assessing the role of Chinese language tour guides in Danang, Vietnam affecting WOM recommendation of Chinese tourists through their performance.

\subsection{Tourist satisfaction}

Tourist satisfaction plays an important role in the success of destination marketing because it impacts the behavior of destination selection, the use of products and services, WOM and return decision [12]. The literature on customer satisfaction is generally divided into two schools of thought lead by [13] and [14]. The first regarded customer satisfaction as a gap between customers' expectations and their perceptions of a product or service's performance, whereas the second considered customer satisfaction as 'an outcome of the actual quality of performance and its perception by consumers' [15]. Based on these perspectives, tourists' expectations and experiences may affect their satisfaction or dissatisfaction. Given that satisfaction is a multifaceted concept, it is important to evaluate by considering many aspects of the encounter, including products, services, and facilities. In the study of visitor behavior, consideration should be given to tourist needs and the results of such needs, namely, the level of satisfaction with needs and whether tourists are satisfied with their service and/or product experience. The importance of considering issues relating to the perceptions of needs and outcomes was also emphasized by [13].

As for the relationship between the role of tour guide and tourist satisfaction, there are different opinions on the impact of tour guide performance on tourist satisfaction. [16] surveyed 15 tour guides from Israel to Europe and the United States, and found that in most cases, the performance of tour guides did not significantly affect customer satisfaction. Their findings are inconsistent with expectations because it is generally believed that tour guides have the responsibility to customize the tour to personal needs and preferences, so they are highly responsible for achieving tourist satisfaction. In contrast, [17] found that the tour guide performance during the tour can affect tourists' perceptions of the tour. In addition, [3] investigated international tourists' satisfaction with the services provided by local tour guides in Hong Kong. It was found that international tourists were generally satisfied with local tour guides in terms of professional skills, customer relationship/empathy, and communication. According to [4], their research on the role of local tour guides in the satisfaction of international tourists showed that tour guide performance is one of the most important factors affecting the satisfaction of tourists, especially foreign ones. In their research, reviewing relevant literature and focus group interviews were used to identify and measure the skills/attributes of the performance of tour guides. At the same time, through the analysis of three factors affecting the service quality of Macao tour guides, including core service delivery, customer orientation and communication effectiveness, [5] concluded that tour guides are one of the most obvious and key participants in tourism, especially sustainable development. Later, in Mike et al. (2011)'s research, six key issues affecting the service 
The Impacts of Tour Guide Performance on Word of Mouth Recommendation of Chinese Tourists in Vietnam

quality and professionalism of tour guides in Hong Kong and Macao were also identified, including unhealthy tourism business practices, low fares and quality of guidance, recognition of the importance of tour guides, income and training of tour guides, human resources problems and role conflicts of tour guides. Both studies conducted semistructured in-depth interviews with tour guides' associations, monitoring authorities, government officials, tour operators and representatives of selected tour guides from Hong Kong and Macao to determine the skills of tour guides and their measurements. Recently, by reviewing the past and related literature, [18] affirmed the role of tour guides and pointed out that their communication skills enhanced the experience of tour guides and the expectations of tourists. It is also noted that in most research, tour guide performance was assessed by tourists' evaluation.

\subsection{WOM recommendation}

Word of mouth (WOM) is being considered as an important form of promotion, as well as an important source of information affecting consumers' attitudes and buying behavior. WOM is particularly important in tourism, and its intangible products are difficult to evaluate before consumption [19]. According to the Bass model [20], two kinds of communication dominate the buyer's decision: advertising and WOM. In both cases, marketing literature paid more attention to the former than to the latter, probably because it is difficult to study highly informal WOM processes. However, there is evidence that WOM is an important means to find and retain customers [21], especially for some professional services, such as tourism [22].

Recent studies in the field of tourism in a wide range of national studies showed that both positive and negative WOM have an impact on tourism products. Among them, [23] based on a New Zealand-based study and pointed out that negative WOM may have a huge impact on the image of the destination because unsatisfactory visitors disseminate negative comments related to their experiences. [24]'s Caribbean study also warned that when locals show hostility to tourists, the result is negative WOM and a possible downturn in the industry. [25] studied wine tourism in Australia, they found that tourists' WOM recommendations promoted wine sales when vacation opinion leaders returned home and told others about their experiences. [26] found that most travel decisions in Western Australia are based on WOM communication. [23]'s study on tourism marketing in Wales and noted that the potential of WOM as an effective tool for disseminating "Visit Wales" information through foreign visitors. In an American-based study, [27] pointed out that visitors' restaurant choices were mainly influenced by opinion leaders' WOM recommendations, but few decisions were based on more formal media influences.

WOM is considered as an important market phenomenon and a means for tourists to express their satisfaction or dissatisfaction with products [28][29]. It was suggested that informal information obtained through WOM would have a strong impact on customer evaluation of products and sellers and future purchase decisions [30][31]. In other researches, including [32] and [33]'s ones, it has shown the importance of satisfaction as a way of understanding destination performance. A lot of studies examined the effects of destination attributes on revisit and WOM recommendation intentions 
Pham Van Sang

[34][35][12]. Obviously, VOM recommendation is a part of destination loyalty. In this study, the researcher focused on VOM recommendation for finding the solution improving the destination attraction.

\subsection{The mediating role of tourist satisfaction between tour guide performance and the WOM}

Customer satisfaction is regarded as a basic business objective because it is assumed that satisfied customers are more likely to share their experience with others. Therefore, organizations should strive to go beyond simply satisfying customers and building customer's reliability [6]. In terms of tourism, one of the factors directly affecting on the satisfaction of tourists is the performance of tour guides.Generally, satisfied customers with services are more likely to act as free WOM advertising agents, informally introducing networks of friends, relatives, and other potential customers into products or services [36]. [37] asserted that WOM transfers could account for $60 \%$ of new customer sales. Therefore, customer satisfaction has become a basic strategic component of organizations and enterprises. Obviously, the more satisfied customers are, the more likely they are to recommend products or services to encourage others to become customers. It is indicated that tourist satisfaction could bring positive WOM effects to friends and/or relatives. The mediating role of tourist satisfaction between tour guide performance and the WOM recommendation is essential when it is the key factor that has a role as a bridge connecting the guiding service and the behavior of WOM.

A large number of studies have studied the relationship between guiding service and WOM intention through tourist satisfaction. There is a general consensus that when tourists are satisfied with the services (including tour guide service), products and other resources they experience at the destination they visit, their positive impact on relatives and/or colleagues are strengthened [35][38]. Tourism satisfaction related to service quality also plays a mediating role between service quality (tour guiding service) and tourism destination reputation. Therefore, improving service quality (tour guiding service) is a way to develop sustainable tourism because it can improve the satisfaction of tourists, and can be disseminated through more effective tourism marketing [39].

\subsection{Study hypotheses}

In order to obtain all the objectives and further analyses, this study hypothesizes that:

- H1: The higher level of explicit attitude, skills, and professional competence of tour guide are positively associated with the higher level of tourist satisfaction.

- $\quad \mathrm{H} 2$ : The higher level of tour guide performance and tourist satisfaction are positively associated with the higher level of WOM recommendation.

- H3: Tourist satisfaction mediates the relationship between tour guide performance and WOM recommendation.

As being outlined in Figure 1, there is a strong link between tour guide performance, tourist satisfaction and WOM recommendation concerning the consumption of tourism products. These elements are proposed as indicators of travel behavior. 
The Impacts of Tour Guide Performance on Word of Mouth Recommendation of Chinese Tourists in Vietnam

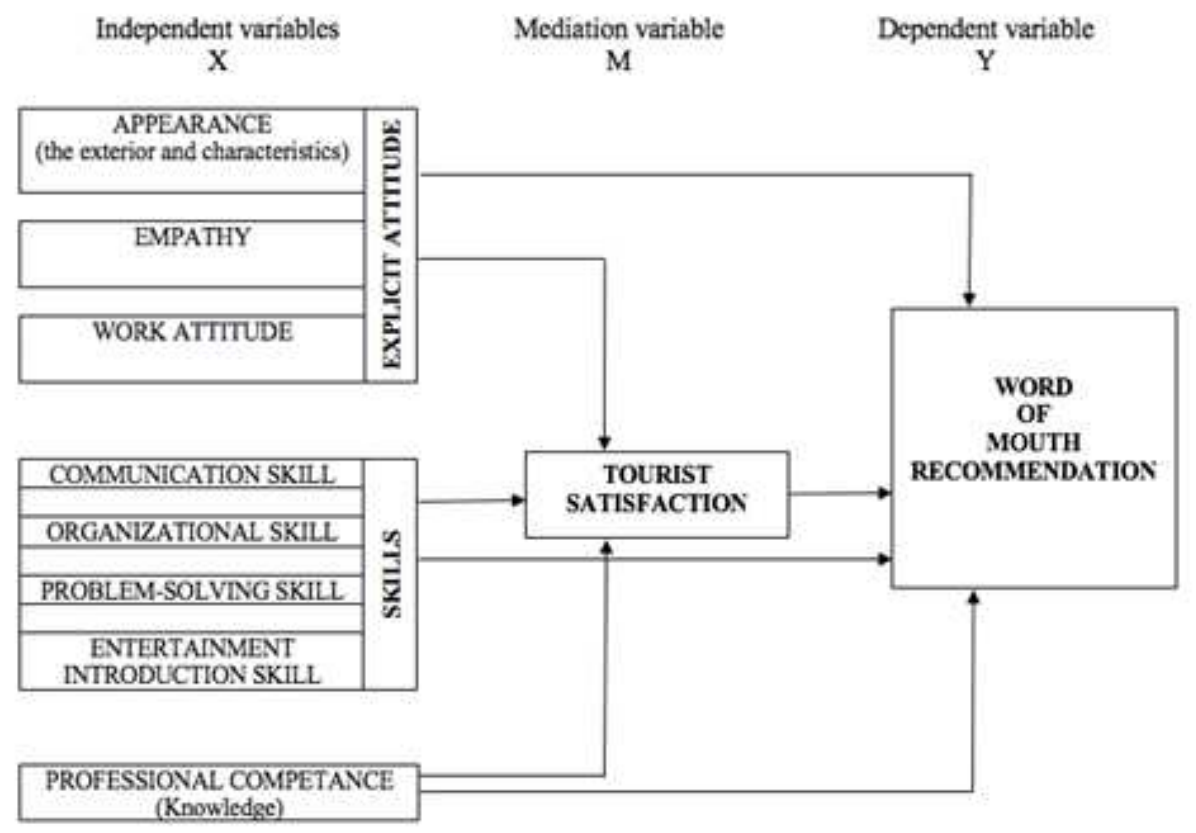

Figure 1: Research model of the study

\subsection{Research methodology}

The sample population includes mainland China residents who visit Danang city, Vietnam as part of the package tour. A questionnairewas executed to undertake in Danang city, Vietnam from June 2019 to August 2019. There were 500 Chinese tourists answered the questionnaire.However, because some respondence were invalid due to some mistakes from tourists,such as the same answer for most questions, none-fill for most questions. 449 respondents were used for this study, making up 89,8\% of totally 500 tourists answering the questionnaires. The questionnaire is mainly used to evaluate tour guide performance in a package tour. Respondents will be asked to indicate their perceptions of the various attributes using a 5-point Likert-type scale with 1 indicating 'strongly disagree' and 5 indicating 'strongly agree'. Then, SPSS and AMOS will be used for data input purposes.

The majority of the scale items were adopted from prior works in tourism and hospitality literature but modified slightly for this research context. Those items regarding tour guides' performance were integrated and adapted from [40][41][42][43][4][8]. The measures for tourist satisfaction were taken from [44],[45] and other prior literature. The scale item for the WOM intention was modified from [46] and [47].

\section{Data analysis}

The results from the questionnaires are analyzed using a statistics program. Descriptive statistics such as frequency, mean, and standard deviation are derived to examine tourists' socio-demographic profiles. Exploratory factor analysis, confirmatory factor analysis and 


\section{Pham Van Sang}

regression analysis statistics are used to examine the relationship between attributes to assess how the performances of tour guides influence the WOM recommendation of Chinese tourists.

\subsection{Socio-demographic profiles}

Tables 1 show the socio-demographic profiles of the respondents. There are more female respondents than male respondents, and the proportion of young respondents is higher (53\% of respondents under 40 years old). A large proportion of respondents are married and single accounting for $88 \%$ of respondents. Education level range from high school and below (18\%) to post-graduate (18.3\%). Most respondents have an income from 3001 to $8000 \mathrm{RMB} /$ month (approximately $50 \%$ ).

Table 1: Socio-demographics of Chinese tourists

\begin{tabular}{|c|c|c|}
\hline Chinese tourists $(n=449)$ & Number & Percentage \\
\hline \multicolumn{3}{|l|}{ Gender } \\
\hline Male & 208 & 46.3 \\
\hline Female & 241 & 53.7 \\
\hline \multicolumn{3}{|l|}{ Age (years) } \\
\hline $18-29$ & 138 & 30.7 \\
\hline $30-39$ & 100 & 22.3 \\
\hline $40-49$ & 52 & 11.6 \\
\hline $50-59$ & 92 & 20.5 \\
\hline More than 60 & 67 & 14.9 \\
\hline \multicolumn{3}{|l|}{ Marital status } \\
\hline Married & 253 & 56.4 \\
\hline Single & 142 & 31.6 \\
\hline Divorced & 32 & 7.1 \\
\hline Widow(er) & 22 & 4.9 \\
\hline \multicolumn{3}{|l|}{ Education level } \\
\hline High school and below & 81 & 18.0 \\
\hline Non-degree (college) & 94 & 20.9 \\
\hline University degree & 192 & 42.8 \\
\hline Post-graduate & 82 & 18.3 \\
\hline \multicolumn{3}{|l|}{ Monthly income (RMB) } \\
\hline Less than 2000 & 36 & 8.0 \\
\hline $2001-3000$ & 52 & 11.6 \\
\hline $3001-5000$ & 123 & 27.4 \\
\hline $5001-8000$ & 99 & 22.0 \\
\hline $8001-12000$ & 81 & 18.0 \\
\hline $12001-20000$ & 30 & 6.7 \\
\hline More than 20000 & 28 & 6.2 \\
\hline
\end{tabular}

Source: Survey results 2019 
The Impacts of Tour Guide Performance on Word of Mouth Recommendation of Chinese Tourists in Vietnam

\subsection{Reliability and exploratory factor analysis}

For the independent variables and mediator, after analyzing Cronbach's Alpha for each group of attributes, the APP6 'Tour guide had good health" was deleted because it had the Corrected item - Total Correlation lower than .3. Other results for other groups of attributes (APP, EMP, WAT, COM, ORG, PRS, ENT, PRO, SAT) were satisfied in terms of Cronbach's Alpha Analysis.

Table 2:

\begin{tabular}{|c|c|c|}
\hline Independent Variables & Number of items & Alpha \\
\hline Appearance (APP) & $\overline{5}$ & 0.836 \\
\hline Empathy (EMP) & 3 & 0.777 \\
\hline Work Attitude (WAT) & 3 & 0.765 \\
\hline Communication skill (COM) & 3 & 0.824 \\
\hline Organizational skill (ORG) & 3 & 0.851 \\
\hline Problem-solving skill (PRS) & 5 & 0.791 \\
\hline $\begin{array}{l}\text { Entertainment introduction skill } \\
\text { (ENT) }\end{array}$ & 3 & 0.836 \\
\hline Professional competence (PRO) & 3 & 0.723 \\
\hline Tourist satisfaction (SAT) & 3 & 0.790 \\
\hline
\end{tabular}

After conducting Exploratory factor Analysis (EFA) to identify tour guide performance dimensions using the Principal Axis Factoring with Promax rotation, ENT was eliminated, othereight factors were derived from factor analysis with 28 performance items were kept.The Kaiser-Meyer-Olkin (KMO) measure of sampling adequacy was 0.891 and Sig. $<0.05$ in Bartlett's test, which means the EFA is suitable. The eight factors explained $66.430 \%$ of the total variance of the remaining items. The eight factors were also labeled as APP (APP1, APP2, APP3, APP4, APP5) stands for Appearance, EMP (EMP1, EMP2, EMP3) stands for Empathy, WAT (WAT1, WAT2, WAT3) stands for Work Attitude, COM (COM1, COM2, COM3) stands for Communication skill, ORG (ORG2, ORG3, ORG4) stands for Organizational skill, PRS (PRS1, PRS2, PRS3, PRS4, PRS5) stands for Problem-solving skill, PRO (PRO1, PRO2, PRO3) stands for Professional competence skill, and SAT (SAT1, SAT2, SAT3) stands for Tourist satisfaction.

\subsection{Confirmatory factor analysis}

The proposed model of this research generally held with data from Chinese tourist sample. The model fit indices showed in Table 4 thatCMIN/df $=1.202$ (less than 3); RMSEA $=0.021$ (less than 0.08); IFI $=0.986, \mathrm{CFI}=0.986$ (more than 0.9); NFI $=0.921$, $\mathrm{RFI}=0.907, \mathrm{GFI}=0.942, \mathrm{AGFI}=0.927$ (more than 0.8); $\mathrm{PCFI}=0.840, \mathrm{PNFI}=0.784$ (more than 0.5 ). The indicators are basically within acceptable value, so the model fit and data are good. 
Pham Van Sang

Table 3: Factor loading from Pattern Matrix

\begin{tabular}{|c|c|c|c|c|c|c|c|c|}
\hline & \multicolumn{8}{|c|}{ Factor } \\
\hline & APP & PRS & $\mathrm{COM}$ & ORG & WAT & EMP & SAT & PRO \\
\hline APP1 & 0.804 & & & & & & & \\
\hline APP2 & 0.772 & & & & & & & \\
\hline APP4 & 0.745 & & & & & & & \\
\hline APP5 & 0.684 & & & & & & & \\
\hline APP3 & 0.675 & & & & & & & \\
\hline PRS5 & & 0.767 & & & & & & \\
\hline PRS1 & & 0.738 & & & & & & \\
\hline PRS4 & & 0.713 & & & & & & \\
\hline PRS2 & & 0.678 & & & & & & \\
\hline PRS3 & & 0.652 & & & & & & \\
\hline COM2 & & & 0.846 & & & & & \\
\hline COM1 & & & 0.843 & & & & & \\
\hline COM3 & & & 0.825 & & & & & \\
\hline ORG3 & & & & 0.784 & & & & \\
\hline ORG2 & & & & 0.780 & & & & \\
\hline ORG4 & & & & 0.768 & & & & \\
\hline WAT1 & & & & & 0.799 & & & \\
\hline WAT3 & & & & & 0.732 & & & \\
\hline WAT2 & & & & & 0.731 & & & \\
\hline EMP1 & & & & & & 0.792 & & \\
\hline EMP3 & & & & & & 0.760 & & \\
\hline EMP2 & & & & & & 0.704 & & \\
\hline SAT1 & & & & & & & 0.788 & \\
\hline SAT2 & & & & & & & 0.703 & \\
\hline SAT3 & & & & & & & 0.691 & \\
\hline $\mathrm{PRO} 2$ & & & & & & & & 0.818 \\
\hline PRO1 & & & & & & & & 0.735 \\
\hline PRO3 & & & & & & & & 0.725 \\
\hline
\end{tabular}

Table 4: Model fit indicates

\begin{tabular}{|c|c|c|c|c|c|c|c|c|c|c|c|c|c|}
\hline & df & CMIN & CMIN/df & P & RMSEA & NFI & CFI & IFI & RFI & GFI & AGFI & PCFI & PNFI \\
\hline Value & 322 & 386.916 & 1.202 & 0.008 & 0.021 & 0.921 & 0.986 & 0.986 & 0.907 & 0.942 & 0.927 & 0.840 & 0.784 \\
\hline
\end{tabular}

3.4. Relationships between Tourist satisfaction, the WOM recommendation and Independent variables

In order to determine which factors are related to the dependent variable of WOM recommendation, Pearson correlation (r) was applied in this study. Table 5 presented the presence of positive correlations between dependent variables WOM and SAT $(r=0.616$, $\mathrm{p}<0.001)$, between WOM and independent variables: APP $(\mathrm{r}=0.471, \mathrm{p}<0.001)$; WAT $(\mathrm{r}$ $=0.520, \mathrm{p}<0.001)$; COM $(\mathrm{r}=0.403, \mathrm{p}<0.001)$; EMP $(\mathrm{r}=0.515, \mathrm{p}<0.001)$; PRS $(\mathrm{r}=$ 
The Impacts of Tour Guide Performance on Word of Mouth Recommendation of Chinese Tourists in Vietnam

$0.418, \mathrm{p}<0.001)$; ORG $(\mathrm{r}=0.499, \mathrm{p}<0.001)$; PRO $(\mathrm{r}=0.412, \mathrm{p}<0.001)$. These figures meant that if APP, WAT, COM, EMP, PRS, ORG, PRO and SAT are improved; they can lead to better tourists' Word-of-Mouth.

Table 5: Correlation between variables

\begin{tabular}{|c|c|c|c|c|c|c|c|c|c|}
\hline & WOM & 1 & 2 & 3 & 4 & 5 & 6 & 7 & 8 \\
\hline 1.SAT & $0.616^{*}$ & 1 & & & & & & & \\
\hline 2.APP & $0.471^{*}$ & $0.459^{*}$ & 1 & & & & & & \\
\hline 3.WA & $\underset{*}{0.520^{*}}$ & $0.435^{*}$ & $0.444^{*}$ & 1 & & & & & \\
\hline $4 . \mathrm{CO}$ & $0.403^{*}$ & $0.314^{*}$ & 0.089 & $0.142^{*}$ & 1 & & & & \\
\hline $\begin{array}{l}\text { M } \\
\text { 5.EMP }\end{array}$ & $0.515^{*}$ & $0.444^{*}$ & $0.477^{*}$ & $0.495^{*}$ & $0.137^{*}$ & 1 & & & \\
\hline 6.PRS & $0.418^{*}$ & $0.378^{*}$ & $0.118^{*}$ & $0.145^{*}$ & $0.267^{*}$ & $0.216^{*}$ & 1 & & \\
\hline 7.ORG & $0.499^{*}$ & $0.415^{*}$ & $0.292^{*}$ & $0.430^{*}$ & $0.250^{*}$ & $0.404^{*}$ & $0.338^{*}$ & 1 & \\
\hline 8.PRO & $0.412^{*}$ & $0.346^{*}$ & $0.125^{*}$ & $0.212^{*}$ & $0.202^{*}$ & $0.193^{*}$ & $0.410^{*}$ & $0.313^{*}$ & 1 \\
\hline Mean & 4.18 & 4.13 & 4.22 & 4.39 & 4.21 & 4.28 & 4.13 & 4.31 & 4.38 \\
\hline SD & 0.565 & 0.638 & 0.642 & 0.611 & 0.708 & 0.663 & 0.596 & 0.689 & $\begin{array}{c}0.57 \\
2\end{array}$ \\
\hline te: & $\begin{array}{l}\text { Corr } \\
\text { Correl }\end{array}$ & $n$ is & ical & the 0 & $\begin{array}{l}\text { evel } \\
\text { jel ( }\end{array}$ & $\begin{array}{l}\text { iled). } \\
\text { led). }\end{array}$ & & & \\
\hline
\end{tabular}

\subsection{Regression analysis}

To test the mediating effect, firstly we do the regression analysis of independent variables and mediating variables; secondly, we do the regression analysis of independent variables and dependent variables; third, we include all variables in the regression analysis at the same time. Before the regression analysis, the research dealt with the control variables as follows: gender, age, education level, income and marital status were dummy variables. Specifically, 1 is male, 0 is female; 1 is $18-39$ years old, 0 is 40 years old and more; 1 is post-graduate, 0 is below post-graduate; 1 is $5000 \mathrm{RMB}$ and less, 0 is $5000 \mathrm{RMB}$ and more; 1 is married, 0 is others.

Table 6 shows the regression analysis results. Model 1 and model 2 tested tour guide performance's impact on tourist satisfaction. Model1 takes the control variables into the regression mode. Also, it turned out that marital status has a great impact on tourist satisfaction $(\beta=0.317, \mathrm{p}<0.05)$, gender and income show no effect with $\mathrm{p}>0.05$. Model 2 takes the tour guide performance's factors into regression model,then the total of sevenindependent variables have positive effects on tourist satisfaction. They are APP ( $\beta$ $=0.218, \mathrm{p}<0.05)$, WAT $(\beta=0.144, \mathrm{p}<0.05), \mathrm{COM}(\beta=0.127, \mathrm{p}<0.05), \operatorname{EMP}(\beta=$ 
Pham Van Sang

$0.118, p<0.05)$, PRS $(\beta=0.144, p<0.05)$, ORG $(\beta=0.086, p<0.05)$, PRO $(\beta=0.140, p$ $<0.05)$. ORGis the weakest of seven factors while APP comes first on the list.It shows that the explicit attitude (friendly, punctual, polite and honest) of the Vietnamese tour guide has a great influence onthe satisfaction of Chinese tourists. The coefficient of determination $\left(\mathrm{R}^{2}\right)$ in the model 2 represents the results of the regression analysis that can be perceived as 48.3 percent confirming a result in terms of predicting the variance of the travelers' overall satisfaction levels with the seven factors of tour guide performance. This result also confirms that $\mathrm{H} 1$ is supported, which means that a higher level of personality, skills, and professional competence of tour guides is positively associated with a higher level of tourist satisfaction.

Table 6: Regression analyses

\begin{tabular}{|c|c|c|c|c|c|c|}
\hline \multirow[t]{2}{*}{ Variables } & \multicolumn{2}{|c|}{ SAT } & \multicolumn{4}{|c|}{ WOM } \\
\hline & Model 1 & Model 2 & Model 3 & Model 4 & Model 5 & Model 6 \\
\hline \multicolumn{7}{|l|}{ Control variable } \\
\hline Gender & 0.017 & -0.029 & 0.025 & -0.029 & 0.015 & -0.024 \\
\hline Age & $0.224^{* * * *}$ & $0.176^{* * *}$ & $0.154^{* * * *}$ & $0.089^{* * * *}$ & 0.018 & 0.055 \\
\hline Edu level & $-0.110^{* * *}$ & -0.047 & -0.070 & 0.012 & -0.003 & 0.021 \\
\hline Marital status & $0.317^{* * * *}$ & $0.191^{* * * *}$ & $0.197^{* * * *}$ & 0.047 & 0.005 & 0.011 \\
\hline Income & $0.089^{*}$ & 0.036 & 0.081 & 0.021 & 0.027 & 0.014 \\
\hline \multicolumn{7}{|c|}{ Independent variable } \\
\hline APP & & $0.218^{* * * *}$ & & $0.196^{* * * *}$ & & $0.154^{* * * *}$ \\
\hline WAT & & $0.144^{* * * *}$ & & $0.206^{* * *}$ & & $0.178^{* * * *}$ \\
\hline $\mathrm{COM}$ & & $0.127^{* * * *}$ & & $0.214^{* * *}$ & & $0.190^{* * *}$ \\
\hline EMP & & $0.118^{* * *}$ & & $0.162^{* * *}$ & & $0.139^{* * * *}$ \\
\hline PRS & & $0.144^{* * *}$ & & $0.151^{* * *}$ & & $0.123^{* * * *}$ \\
\hline ORG & & $0.086^{* * *}$ & & $0.126^{* * *}$ & & $0.110^{* * * *}$ \\
\hline PRO & & $0.140^{* * * *}$ & & $0.165^{* * *}$ & & $0.138^{* * * *}$ \\
\hline \multicolumn{7}{|c|}{ Mediating variable } \\
\hline SAT & & & & & $0.606^{* * * *}$ & $0.193^{* * *}$ \\
\hline $\mathrm{R}^{2}$ & 0.158 & 0.483 & 0.065 & 0.576 & 0.373 & 0.594 \\
\hline$\Delta \mathrm{R}^{2}$ & 0.158 & 0.325 & 0.065 & 0.511 & -0.203 & 0.221 \\
\hline $\mathrm{F}$ & $17.828^{* * * *}$ & $35.928^{* * * *}$ & $7.240^{* * * *}$ & $51.654^{* * * *}$ & $45.382^{* * * *}$ & $51.403^{* * * *}$ \\
\hline
\end{tabular}

(Notice: $* * *$ means $\mathrm{p}<0.01, * *$ means $\mathrm{p}<0.05$, * means $\mathrm{p}<0.1$ )

According to model 6 , there were eight independent variables had effects on WOM. They are APP $(\beta=0.154, \mathrm{p}<0.05)$, WAT $(\beta=0.178, \mathrm{p}<0.05), \operatorname{COM}(\beta=0.190$, $\mathrm{p}<0.05), \operatorname{EMP}(\beta=0.139, \mathrm{p}<0.05), \operatorname{PRS}(\beta=0.123, \mathrm{p}<0.05)$, ORG $(\beta=0.110, \mathrm{p}<0.05)$, PRO $(\beta=0.138, p<0.05)$, and $\operatorname{SAT}(\beta=0.193, \mathrm{p}<0.05)$. SAT and COM have the strongest effects. The coefficient of determination $\left(\mathrm{R}^{2}\right)$ in the model 6 represents the results of the regression analysis that can be perceived as 59.4 percent confirming a result in terms of predicting the variance of WOM. This means tour guide performance and tourist satisfaction have positive impact on WOM, in other words, $\mathrm{H} 2$ is supported.

\subsection{Mediating effect of tourist satisfaction}

According to [48], the establishment of mediation must be met by three conditions. First, the independent variables (tour guide performance) must be related to the mediator (tourist satisfaction). Secondly, mediators (tourist satisfaction) must be related to dependent variables (WOM recommendation). Third, a significant relationship between the independent variables (tour guide performance) and a dependent variable (WOM recommendation) will be reduced (partial mediation) or no longer be significant (full 
The Impacts of Tour Guide Performance on Word of Mouth Recommendation of Chinese Tourists in Vietnam

mediation) when controlling for the mediator (tourist satisfaction). The first and second condition have been met as described above.

In order to test for a mediation model in which tourist satisfaction mediates the relationship between tour guide performance and the WOM, additional regression analyses were conducted in which the WOM were regressed on the tour guide performance alone and then again with the tourist satisfaction measures controlled.In model 4, the total effect of tour guide performance on the WOM is 1.22. Model 6 added tourist satisfaction into the regression equation. Furthermore, it shows that the tour guide performance still has a great effect on the WOM with the total effect of tour guide performance is 1.032. As a result, tourist satisfaction takes a partial mediation effect between tour guide performance and the WOM recommendation. In short, H3 is supported. The relationship between the tour guide performance and the WOM recommendation is partially mediated by tourist satisfaction.

\section{Discussion and recommendation}

\subsection{Discussion of finding}

According to table 6, the tourist satisfaction is the most influential factor to the WOM recommendation of Chinese tourists. The second is the "Communication skill" factor, followed by Empathy, Problem-solving skill, Appearance, Work attitude, Professional competence, and Organizational skill. These factors are listed as their positive $\beta$ values descend, indicating a significant positive impact on the WOM recommendation.From the perspective of management economics, the results of the study should help tourism operators to carry out more targeted marketing activities and guide the development of products for the Chinese market. The socio-demographic of Chinese tourists that have been identified should provide some guidance for future marketing activities. Providing a satisfying experience for Chinese tourists is as important as creating a positive tourism image for Danang city.

In each country, providing the best service and achieving the highest level of customer satisfaction are considered to be the most important factors in the tourism business. 'The success of the tourism industry very much depends on the performance of tour guides in each destination' [49]. According to the finding of this study, when the local Chinese language tour guides in Danang have good personalities, hardworking attitude, good guiding skills and knowledge, the Chinese tourists will be satisfied and willing to recommend others to visit Danang, Vietnam. This model is suitable for Danang city only, however, the same research method can be used to transfer the model to other populations in other countries or regions: the statistical process will create a suitable model related to that country, which can be the same or different from this study.

\subsection{Implications of the study}

The performance of tour guide is one of the keys to the success of the package tour. This study focused on the performance of tour guide and their impact on tourists' satisfaction and WOM recommendation from the perspective of Chinese tourists. The results of this study provide many implications for tour guides, tour managers and travel companies.

This study provides some guidance for strategies from the perspective of tour guide performance. Current research also shows that good tour guides are based on seven 


\section{Pham Van Sang}

aspects: appearance, work attitude, communication skill, empathy, problem-solving skill, organizational skill, and professional competence. Moreover, the performance of tour guides has a positive relationship with tourist satisfaction and WOM recommendation behavior. Firstly, in terms of explicit personality, tour guides should pay more attention to attaching great importance to the neatness and appropriateness of their clothes and improving the ability on understanding tourists' psychology needs as well as always being willing to help tourists. Furthermore, tour guides should show honesty, integrity and a friendly attitude to attract the trust of tourists. Therefore, the role of tour manager and travel company are also very important when providing training programs for tour guides.

Secondly, in terms of skills, tour guides should focus on developing their ability of time management and activities by understanding their tourists. At the same time, the tour manager and travel company must design the suitable tourprogram according to the schedule and activities. On the other hand, tour guidesshould have good relationships with other staff, such as drivers, other tour guides at destinations or hotel staff. Third, in terms of professional competence, tour guides need to learn and read more books/news/magazines to enhance their understanding of the culture and history of the destination, as well as the Chinese culture. As a result, tour manager and travel company may also offer short-term internal courses to improve tour guide knowledge. Besides, the ability of tour guides to handle complaints and solve problems or conflicts in the package tour is an important factor leading to the success of the package tour. Therefore, a tour guide must be keen to be aware of all the anomalies happened during the trip. They should also be judicious in solving problems, so as to avoid disagreements among tourists which may damage the atmosphere of tour. Again, that is why it is an important skill for tour guides to understand Chinese culture.

Finally, the study also shows some advicesfor people who are leaders in the tourism industry in Vietnam. With the efforts of tour guides and the support of tour managersand travel companies, there should be a new innovative system or certificate to evaluate qualified tour guides beforeentering the tour market. The system or certificate must emphasize the important knowledge and skills of the tour guide, including the understanding of the culture and history of the destination, the understanding of the culture of foreign tourists, the skills to solve problems and conflicts, the skills to organize time management and activities, and the competence of foreign language. This not only satisfies the tour guide's attribute but also enhance the level of foreign tourists' satisfaction in the package tour and gain tourists' trust to be willing to recommend Vietnam to others.

\subsection{Limitations of the study and future research}

First of all, the limitation of this research lies in the convenient sampling method. Due to time, finance, location and human resources restrictions, the researcher can only provide surveys to tourists at popular destinations in Danang City. Therefore, the results of the study cannot represent the views of all Chinese tourists about their tour guide.

Future research can use a larger sample size to test the dimensions of tour guide performance in other ethnic and cultural backgrounds. In Vietnam's tourism industry, the unethical behavior of tour guides has aroused a lot of public debate and the attention of 
The Impacts of Tour Guide Performance on Word of Mouth Recommendation of Chinese Tourists in Vietnam

policymakers. In the future, the research on tour guide can also explore the influence of tour guide's abnormal or unexpected behaviors on tourists' satisfaction.

\section{Conclusions}

This study showed the close relationship between tour guide performance, tourist satisfaction and WOM recommendation of Chinese tourists in Danang city, Vietnam based on the package tour. The study also proposes a multidimensional model, which consists of seven components of tour guide performance (appearance, work attitude, communication skill, empathy, problem-solving skill, organizational skill, and professional competence). These components can be regarded as the most effective factors to build tourist satisfaction and the behavior of WOM recommendation. In addition, the study also provides many suggestions for tour guides and tour managers to identify the advantages and disadvantages of tour guide attributes in travel companies, and then promote and improve the performance of employees with higher customer satisfaction and their loyalty to destinations. Also, these recommendations will help Vietnamese policymakers to establish an innovative qualification standard system for inbound tour guides, so as to adopt global standards on a global scale. In short, the performance of tour guides not only affects the success of the package tour but also plays an important role in establishing the image of Vietnam's tourism industry.

\section{REFERENCES}

1. BEM.King, and M.Mcvey, China outbound, Travels and Tourism Analysis, 1 (2003) $1-32$.

2. H.Qu and I.Li, The characteristics and satisfaction of mainland Chinese visitors to Hong Kong, Journal of Travel Research, 35(4) (1997) 37-41.

3. A.Wong, Satisfaction with local tour guides in Hong Kong, Pacific Tourism Review, 5 (2001) 59-67.

4. S.Huang, H.C.Cathy and A.Chan, Tour guide performance and tourist satisfaction: a study of the package tours in Shang Hai, Journal of Hospitality and Tourism Research, 34 (2010) 3-33.

5. A.H.N.Mak, K.K.F.Wong and R.C.Y.Chang, Factors affecting the service quality of the tour guiding profession in Macau, International Journal of Tourism Research, 12 (2010) 205-218.

6. H.L.Nguyen, The impacts of tour guide performance on foreign tourist satisfaction and destination loyalty in Vietnam, (2015).

7. H.Kong, C.Cheung and T.Baum, Are tour guides in China ready for the booming tourism industry, Journal of China Tourism Research, 5 (2009) 65-76.

8. V.C.S.Heung, Effects of tour leader's service quality on agency's reputation and customers Word-Of-Mouth, Journal of Vacation Marketing, 14 (4) (2008) 305-15.

9. C.Liu, W.Lin and Y.Wang, Relationship between self-congruityand destination loyalty: differences between first-time and repeat visitors, Journal of Destination Marketing and Management, 1 (2012) 118-123.

10. T.H.Truong and D.Foster, Using HOLSAT to evaluate tourist satisfaction at destinations: the case of australian holidaymakers in Vietnam, Tourism Management, 27 (2006) 842-855. 


\section{Pham Van Sang}

11. T.H.Truong and B.King, An evaluation of satisfaction levels among chinese tourists in Vietnam, International Journal of Tourism Research, 11(2009) 521- 535.

12. M.Kozak and M.Rimmington, Tourist satisfaction with Mallorca, Spain as an offseason holiday destination, Journal of Travel Research, 39(3) (2000) 260-269.

13. A.Parasuraman, A.Zeithaml and L.Berry, A concept model of service quality and its implications for future research, Journal of Marketing, 49(3) (1985) 41-50.

14. C.Gronroos, A service quality model and its marketing implications, European Journal of Marketing, 18(4) (1984) 36-44.

15. M.Kozak and M.Rimmington, Measuring tourist destination competitiveness: conceptual considerations and empirical findings, International Journal of Hospitality Management, 18(3) (1999) 273-283.

16. A.Geva and A.Goldman, Satisfaction measurement in guided tours, Annals of Tourism Research, 18 (1991) 177-185.

17. L.L.Mossberg, Tour leaders and their importance in charter tours, Tourism Management, 16 (1995) 437-445.

18. B.Weiler and K.Walker, Enhancing the visitor experience: reconceptualising the tour guide's communicative role, Journal of Hospitality \& Tourism Management, to appear.

19. M.R.Jalilvand, Word-of-mouth vs. mass media: their contributions to destination image formation, Anatolia, 28(2) (2017) 151-162.

20. V.Mahajan, E.Muller and F.M.Bass, New product diffusion models in marketing: a review and direction for research, Journal of Marketing, 54 (1990) 1-26.

21. D.F.Duhan, S.D.Johnson, J.B.Wilcox and G.D.Harrell, Influence on consumer use of word-of-mouth recommendation sources, Journal of the Academy of Marketing Science, 25(4) (1997) 283-95.

22. P.H.Reingen and J.B.Kernan, Networks in marketing: methods and illustration, Journal of Marketing Research, 13 (1986) 370-378.

23. N.J.Morgan, A.Pritchard and R.Piggott, Destination branding and the role of the stakeholders: the case of New Zealand, Journal of Vacation Marketing, 9(3) (2003) 285-99.

24. A.P.Crick, Internal marketing of attitudes in Caribbean tourism, International Journal of Contemporary Hospitality Management, 15(3) (2003) 161-166.

25. M.O'Neill, A.Palmer and S.Charters, Wine production as a service experience - the effects of service quality on wine sales, The Journal of Services Marketing, 16(4) (2002) 342-62.

26. T.Shanka, J.Ali-Knight and J.Pope, Intrastate travel experiences of international students and their perceptions of Western Australia as a tourist destination, Tourism and Hospitality Research, 3(3) (2002) 245-56.

27. S.W.Litvin, J.E.Blose and S.T.Laird, Tourist use of restaurant web-pages: is the internet a critical marketing tool?, Journal of Vacation Marketing, 11(2) (2004) 15561.

28. K.B.Murray, A test of services marketing theory: consumer information acquisition activities, Journal of Marketing, 55(1) (1991) 10-25.

29. D.Gremler, Word-of-mouth communication: causes and consequences, Marketing Review, 1 (1994) 3. 
The Impacts of Tour Guide Performance on Word of Mouth Recommendation of Chinese Tourists in Vietnam

30. M.L.Richins, Negative word-of-mouth by dissatisfied consumers: a pilot study, Journal of Marketing, 47(1) (1983) 68-78.

31. W.H.Bolcn, The role of word-of-mouth 'advertising' in retailing, American Business Review, 12(2) (1994) 11-14.

32. A.Pizam, Y.Neumann and A.Reichel, Dimensions of tourism satisfaction with a destination area, Annals of Tourism Research, 5 (1978) 314-322.

33. P.J.Danaher and N.Arweiler, Customer satisfaction in the tourist industry: a case study of visitors to New Zealand, Journal of Travel Research, 34(1) (1996) 89-93.

34. G.F.Ross, Ideal and actual images of back packer visitors to northern Australia, Journal of Travel Research, 32(2) (1993) 54-57.

35. D.A.Baker and J.L.Crompton, Quality, satisfaction and behavioral intentions, Annals of Tourism Research, 27(3) (2000) 785-804.

36. S.Stowe and R.C.Lewis, Customer loyalty: the future of hospitality marketing, (1999).

37. F.F.Reichheld and E.Sasser, Zero defections: quality comes to services, Harvard Business Review, 68 (1990) 105-111.

38. S.M.Meng, G.S.Liang and S.H.Yang, The relationships of cruise image, perceived value, satisfaction and post-purchase behavioral intention on Taiwanese tourists, Afr. J. Bus. Manag., 5 (2011) 19-29.

39. M.M.Okello and S.Yerian, Tourist satisfaction in relation to attractions and implications for conservation in the protected areas of the Northern Circuit, Tanzania, J. Sustain. Tour., 17 (2009) 605-625.

40. D.S.Al Jahwari, E.Sirakaya-Turk, and V.Altintas, Evaluating communication competency of tour guides using a modified importance-performance analysis (MIPA), International Journal of Contemporary Hospitality Management, 28(1) (2016) 195-218.

41. J.Carmody, Intensive tour guide training in regional Australia: an analysis of the Savannah Guides organisation and professional development schools, Journal of Sustainable Tourism, 21(5) (2013) 679-694.

42. A.M.Pereira, Tour guides and destination image: evidence from Portugal, Journal of Tourism and Hospitality Management, 3(7-8) (2015) 129-150.

43. R.Maja and J.Milan, Market orientation of business schools and development of professional competencies of students in the tourism business, 10(1) (2016) 53-62.

44. C.Chi and H.Qu, Examining the structural relationships of destination image, tourist satisfaction and destination loyalty: An integrated approach, Tourism Management, 29 (2008) 624- 636.

45. V.Zabkar, M.M.Brencic and T.Dmitrovic, Modelling perceived quality, visitor satisfaction and behavioral intentions at the destination level, Tourism Management, 31(4) (2010) 537-546.

46. K.Kim, Z.Hallab and J.N.Kim, The moderating effect of travel experience in a destination on the relationship between the destination image and the intention to revisit, Journal of Hospitality Marketing \& Management, 12(5) (2012) 486-505.

47. V.Quintal and A.Polczynski, Factors influencing tourists' revisit intentions, Asia Pacific Journal of Marketing and Logistics, 22(4) (2010) 554-578. 


\section{Pham Van Sang}

48. R.M.Baron and D.A.Kenny, The moderator-mediator variable distinction in social psychological research: conceptual, strategic, and statistical considerations, Journal of Personality and Social Psychology, 51(6) (1986) 1173-1182.

49. H.Q.Zhang and I.Chow, Application of importance-performance model in tour guides' performance: evidence from mainland Chinese outbound visitors In Hong Kong, Tourism Management, 25 (2004) 81-91. 